\title{
Azidothymidine inhibits cell growth and telomerase activity and induces DNA damage in human esophageal cancer
}

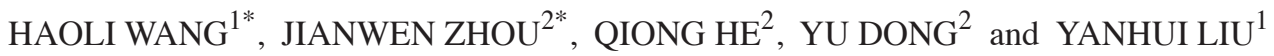 \\ ${ }^{1}$ Department of Pathology, Guangdong General Hospital, Guangdong Academy of Medical Science; \\ ${ }^{2}$ Department of Pathology, First Affiliated Hospital, Sun Yat-sen University, Guangzhou, Guangdong 510080, P.R. China
}

Received March 10, 2016; Accepted February 27, 2017

DOI: $10.3892 / \mathrm{mmr} .2017 .6549$

\begin{abstract}
Esophageal cancer is one of the most common type of malignancies. Telomerase activity, which is absent or weakly detected in the majority of human somatic cells, is elevated in esophageal cancer. Although azidothymidine (AZT), a reverse transcriptase inhibitor, has been utilized as a treatment for tumors, its role in treating esophageal cancer has not been confirmed. The aim of the present study was to determine the effect of AZT on telomerase activity and the proliferation of the human esophageal cancer cell line TE-11. A telomeric repeat amplification assay was utilized to detect telomerase activity following treatment of TE-11 cells with AZT. The effect of AZT on TE-11 cell cycle distribution was determined by flow cytometry. Cellular DNA damage was evaluated by a comet assay and an MTT assay demonstrated that AZT significantly inhibited the viability of TE-11 cells, in a time-and dose-dependent manner. In addition, TE-11 cells treated with various concentrations of AZT exhibited a significant reduction in telomerase activity and percentage of cells in the G1/G0 phase, and an increase in the percentage of cells in the $\mathrm{S}$ phase. High doses of AZT caused DNA damage, and enhanced the expression levels of $\gamma$-H2A histone family member $X$ and phosphorylated checkpoint kinase 2 in TE-11 cells. These results demonstrated that AZT effectively inhibits proliferation of the TE-11 human esophageal cancer cell line in vitro. The growth inhibitory effects were associated with a reduction in telomerase activity, $\mathrm{S}$ and $\mathrm{G} 2 / \mathrm{M}$ phase cell cycle arrest, and enhanced DNA damage, suggesting that AZT may be utilized in the clinic for the treatment of esophageal cancer.
\end{abstract}

Correspondence to: Mrs. Yanhui Liu, Department of Pathology, Guangdong General Hospital, Guangdong Academy of Medical Science, 106 Zhong Shan Second Road, Guangzhou, Guangdong 510080, P.R. China

E-mail: yanh_liu@163.com

${ }^{*}$ Contributed equally

Key words: azidothymidine, esophageal cancer, cell growth, telomerase activity, DNA damage

\section{Introduction}

Telomerase is an RNA nuclear protease that is composed of human telomerase reverse transcriptase (hTERT), human telomerase RNA and a number of associated proteins (1). Telomerase RNA has a short template element that directs the synthesis of telemetric repeats at the end of chromosomes, maintains chromosomal stability, stabilizes telomere length and may promote cancer progression and cell immortality (2). Telomerase activity, which is absent or weakly detected in the majority of human somatic cells, is elevated in immortalized cell lines, stem and germ cells and in $~ 85 \%$ of human cancers, including esophageal cancer (3-5). Esophageal cancer is the eighth most common type of malignancy and is the sixth leading cause of cancer-associated mortality worldwide (6). Incidence rates of esophageal squamous cell carcinoma have been increasing in certain Asian countries. In particular, areas of China contain the highest incidence rates of esophageal cancer in the world (7). Esophageal cancer is the fourth most frequently diagnosed cancer and is the fourth most common cause of cancer-associated mortality in China (8). Despite numerous advances in diagnosis and treatment, the 5-year survival rate for patients diagnosed with esophageal cancer ranges between 15 and 20\% due to the aggressive nature of this type of malignancy (9). Therefore, telomerase activity may represent a useful diagnostic marker for human esophageal cancer and may be a potential target for pharmacological intervention.

Azidothymidine (AZT) is a thymidine analog used in the treatment of acquired immune deficiency syndrome (AIDS). It is phosphorylated to AZT-triphosphate (AZT-TP) by a thymidine kinase enzyme, and in this form, it is incorporated into viral DNA where it acts as a false substitute for viral reverse transcription (RT) and blocks chain elongation. AZT-TP has a high affinity for RT and a low affinity for DNA polymerases $\alpha, \beta$ and $\gamma$. The identification that the hTERT component of telomerase is a functional catalytic RT, prompted studies to inhibit telomerase with RT viral inhibitors, including AZT (10). AZT was demonstrated to inhibit the activity of telomerase and cell growth in various tumor cells in vitro, including those derived from human cancers of the bladder, colon, ovarian, parathyroid, breast and liver (11-16). In the present study, TE-11 cells were treated with AZT and the effect on telomerase activity, cell proliferation, cell cycle progression and DNA damage were investigated. The results suggested that AZT may be a possible clinical therapy for esophageal cancer. 


\section{Materials and methods}

Cell culture and treatments. TE-11 cells, a cell line derived from a patient with human esophageal cancer, were purchased from the American Type Culture Collection and were maintained at $37^{\circ} \mathrm{C}$ and $5 \% \mathrm{CO}_{2}$ in Dulbecco's modified Eagle's medium (DMEM), supplemented with $10 \%$ fetal bovine serum and $100 \mathrm{U} / \mathrm{ml}$ penicillin/streptomycin. AZT was purchased from Sigma-Aldrich; Merck KGaA (Darmstadt, Germany) and dissolved in PBS.

MTT assay. A total of $1 \times 10^{4}$ cells/well were seeded in a 96-well plate. Cells were treated with 2,20, 100 and $200 \mu \mathrm{M}$ AZT for $24,48,72$ and $96 \mathrm{~h}$. The wells were subsequently replaced with $10 \mu \mathrm{l} /$ well MTT solution $(5 \mathrm{mg} / \mathrm{ml})$ and incubated at $37^{\circ} \mathrm{C}$ for $4 \mathrm{~h}$. The supernatant was removed and $100 \mu \mathrm{l} /$ well dimethyl sulfoxide was added for $15 \mathrm{~min}$. The spectrometric absorbance at a wavelength of $490 \mathrm{~nm}$ was measured on a microplate reader (BioTek Instruments, Inc., Winooski, VT, USA). As a control, TE-11 cells were additionally treated with DMEM alone.

Measurement of telomerase activity. TE-11 cells $\left(2 \times 10^{6}\right)$ were cultured in 6-well plates and treated with 2,20,100 and $200 \mu \mathrm{M}$ AZT for $48 \mathrm{~h}$ at $37^{\circ} \mathrm{C}$. Lysates were prepared by treating cells for $30 \mathrm{~min}$ on ice with lysis buffer [10 mM Tris- $\mathrm{HCl}(\mathrm{pH} 7.5)$, $1.5 \mathrm{mM} \mathrm{MgCl} 2,1 \mathrm{mM}$ EGTA, $1 \%$ 3-((3-cholamidopropyl) dimethylammonio)-1-propanesulfonate, $10 \%$ glycerol, $5 \mathrm{mM}$ $\beta$-mercaptoethanol and $0.1 \mathrm{mM}$ phenylmethane sulfonyl fluoride]. Lysates were centrifuged at $15,000 \mathrm{x}$ g for $20 \mathrm{~min}$ at $4^{\circ} \mathrm{C}$. Supernatants were collected and the protein concentrations were determined using a Bicinchoninic Assay kit (Bio-Rad Laboratories, Inc., Hercules, CA, USA). Lysates were subsequently diluted to $10 \mathrm{mg} / \mathrm{ml}$. Telomerase activity was measured by polymerase chain reaction (PCR) and the telomeric repeat amplification (TRAP) assay. The PCR reaction mixture was prepared using TRAP reaction buffer [20 mM Tris- $\mathrm{HCl}$ (pH 8.3), $1.5 \mathrm{mM} \mathrm{MgCl} 2,63 \mathrm{mM} \mathrm{KCl}, 0.005 \%$ Tween-20 and $1 \mathrm{mM}$ EGTA]. The PCR reaction mixture was comprised of $312.5 \mu \mathrm{M}$ dNTP, $0.625 \mu \mathrm{M}$ telomerase substrate (TS) primer, the reverse primer for amplification (CX) and $1 \mathrm{U}$ hot-start Taq DNA polymerase, in a total volume of $50 \mu \mathrm{l}$. In addition, each reaction mixture contained $0.625 \mu \mathrm{M}$ internal control primer (NT) and $0.01 \mathrm{aM}$ internal control template (TSNT) for amplification of a $36 \mathrm{bp}$ internal standard. A total of $1 \mu 1$ lysate was subsequently added to this mixture, which was placed in a thermal cycler. Primers were as follows: 5'-AATCCGTCG AGCAGAGTT-3' for TS; 5'-CCCTTACCCTTACCCTTACCC TAA-3' for CX; 5'-ATCGCTTCTCGGCCTTTT-3' for NT and 5'-AATCCGTCGAGCAGAGTTAAAAGGCCGAGA AGCGAT-3' for TSNT. Cycling conditions were as follows: An initial telomerase extension step at $30^{\circ} \mathrm{C}$ for $30 \mathrm{~min}$, followed by 35 cycles of denaturation at $95^{\circ} \mathrm{C}$ for $30 \mathrm{sec}$, annealing at $50^{\circ} \mathrm{C}$ for $30 \mathrm{sec}$ and extension at $72^{\circ} \mathrm{C}$ for $1 \mathrm{~min}$. For each sample, a total $10 \mu \mathrm{l}$ PCR product was loaded onto $10 \%$ polyacrylamide gels and subjected to electrophoresis at 180-200 V for $\sim 1 \mathrm{~h}$ in Tris/Borate/EDTA buffer. The gel was stained with GelRed $^{\text {TM }}$ (Biotium, Inc., Hayward, CA, USA) and visualized under an ultraviolet (UV) illuminator to determine telomerase activity. An internal control was included and was evident by a 36 bp PCR product. TE-11 cells cultured in DMEM medium alone were utilized as a control, and the band intensities were quantified with ImageJ software (version 1.47; National Institutes of Health, Bethesda, MD, USA).

Cell cycle analysis. Following treatment with 2, 20, 100 and $200 \mu \mathrm{M}$ AZT for $48 \mathrm{~h}, 2 \times 10^{6}$ cells were washed twice with PBS. Following an overnight fixation in $70 \%$ ethanol at $4{ }^{\circ} \mathrm{C}$, cells were harvested by centrifugation at $200 \mathrm{x} \mathrm{g}$ for $10 \mathrm{~min}$ at room temperature and washed twice with PBS. Cells were subsequently stained with propidium iodide and analyzed on the BD FACScan ${ }^{\mathrm{TM}}$ system using BD Accuri C6 Software version 1.0.264.21 (BD Biosciences, Franklin Lakes, CA, USA).

Comet assay. TE-11 cells were cultured for $48 \mathrm{~h}$ in a 6 well plate and treated with 20, 100 and $200 \mu \mathrm{M}$ AZT for $48 \mathrm{~h}$. Additionally, cells treated with DMEM alone served as an untreated control, and cells treated with UV served as a positive control. The Comet assay was performed under alkaline conditions. Cells were resuspended in DMEM at a concentration of $1 \times 10^{5} / \mathrm{ml}$ and were combined with molten LMAgarose (Trevigen, Gaithersburg, MD, USA) (at $37^{\circ} \mathrm{C}$ ) at a ratio of $1: 10$, prior to pipetting $75 \mu \mathrm{l}$ onto CometSlides ${ }^{\mathrm{TM}}$ (Trevigen). Slides were stored in the dark at $4^{\circ} \mathrm{C}$ for $30 \mathrm{~min}$ and immersed in alkaline solution $(0.25 \mathrm{M} \mathrm{NaOH}$ containing $0.1 \mu \mathrm{M}$ EDTA; pH 12.6) at $4^{\circ} \mathrm{C}$ for $2 \mathrm{~h}$. Slides were gently removed from the lysis buffer and rinsed with distilled $\mathrm{H}_{2} \mathrm{O}$. Slides were placed in freshly prepared alkaline solution at $\mathrm{pH}>13$ for $30 \mathrm{~min}$ at room temperature. Gel electrophoresis was performed at $1 \mathrm{~V} / \mathrm{cm}$ for $30 \mathrm{~min}$. Subsequently, slides were washed in $70 \%$ ethanol, stained with GelRed ${ }^{\text {TM }}$ (Biotium, Inc.) and analyzed under a fluorescence microscope at $x 400$ magnification.

Western blot analysis. TE-11 cells were lysed with radioimmunoprecipitation assay buffer (50 mM Tris, $\mathrm{pH} 7.4,150 \mathrm{mM}$ $\mathrm{NaCl}, 1 \%$ TritonX-100, $1 \%$ sodium deoxycholate, $0.1 \%$ SDS, $2 \mathrm{mM}$ sodium pyrophosphate, $25 \mathrm{mM} \beta$-glycerophosphate, $1 \mathrm{mM}$ EDTA, $1 \mathrm{mM} \mathrm{Na}_{3} \mathrm{VO}_{4}$ ) following treatment with 20, 100 and $200 \mu \mathrm{M}$ AZT for $48 \mathrm{~h}$. Protein concentrations were determined using the Bicinchoninic Assay kit (Bio-Rad Laboratories, Inc., Hercules, CA, USA). Heat-denatured protein samples (20 mg/lane) were loaded onto $10 \%$ gels and subjected to electrophoresis prior to transfer onto polyvinylidene fluoride membranes. The membranes were incubated with $5 \%$ bovine serum albumin (Sigma-Aldrich; Merck KGaA) for $1 \mathrm{~h}$ at room temperature. The membranes were then incubated at $4^{\circ} \mathrm{C}$ overnight with the following primary antibodies: Rabbit anti-phosphorylated-checkpoint kinase 2 [pChk2 (Thr68); cat. no. ab85743; 1:1,000; Abcam, Cambridge, MA, USA], mouse anti- $\gamma$-H2A histone family member $\mathrm{X}(\gamma-\mathrm{H} 2 \mathrm{AX}$; cat. no. ab180651; $1: 1,000 ;$ Abcam) and mouse anti- $\beta$-actin (cat. no. sc-8432; 1:1,000; Santa Cruz Biotechnology, Inc., Dallas, TX, USA). Subsequently, membranes were probed with goat anti-rabbit-horseradish peroxidase (-HRP; cat. no. sc2004; 1:5,000; Santa Cruz Biotechnology, Inc.) or goat-anti-mouse-HRP (cat. no. sc2005; 1:5,000; Santa Cruz Biotechnology, Inc.) secondary antibodies for $1 \mathrm{~h}$ at room temperature. Proteins were detected using the Enhanced Chemiluminescence Detection reagent (Pierce; Thermo Fisher Scientific, Inc., Waltham, MA, USA), according to the manufacturer's protocol. 
Table I. Percentage inhibition of AZT on the growth of TE-11 cells.

\begin{tabular}{lcccc}
\hline & \multicolumn{4}{c}{ AZT concentration, $\mu \mathrm{M}$} \\
\cline { 2 - 5 } Time, h & 2 & 20 & 100 & 200 \\
\hline 24 & 4.80 & -2.48 & 0.08 & $16.98^{\mathrm{a}}$ \\
48 & -4.86 & $40.03^{\mathrm{b}}$ & $52.20^{\mathrm{b}}$ & $57.97^{\mathrm{b}}$ \\
72 & -5.58 & $42.21^{\mathrm{b}}$ & $56.37^{\mathrm{b}}$ & $65.87^{\mathrm{b}}$ \\
96 & -8.38 & $45.99^{\mathrm{b}}$ & $67.54^{\mathrm{b}}$ & $76.64^{\mathrm{b}}$
\end{tabular}

${ }^{\mathrm{a}} \mathrm{P}<0.05,{ }^{\mathrm{b}} \mathrm{P}<0.01 \mathrm{vs}$. The control. AZT, azidothymidine.

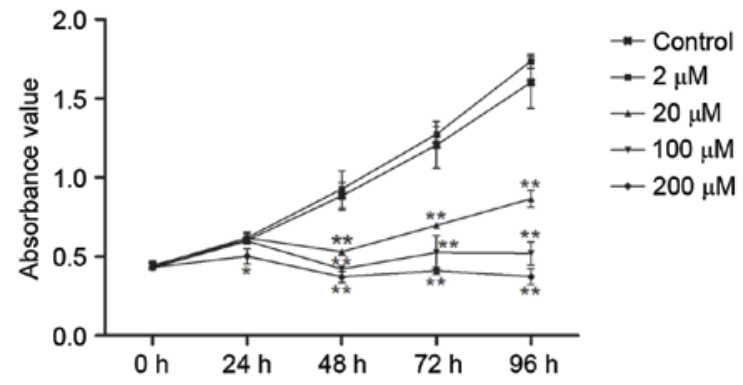

Figure 1. Effect of AZT on TE-11 cell viability. An MTT assay was utilized to measure cell viability in the TE-11 cell line following treatment with 2 , 20, 100 or $200 \mu \mathrm{M}$ AZT for 24, 48, 72 and $96 \mathrm{~h}$. Data are expressed the mean \pm standard deviation of three independent experiments. ${ }^{*} \mathrm{P}<0.05$ and ${ }^{* *} \mathrm{P}<0.01$ vs. Control. AZT, azidothymidine.
A

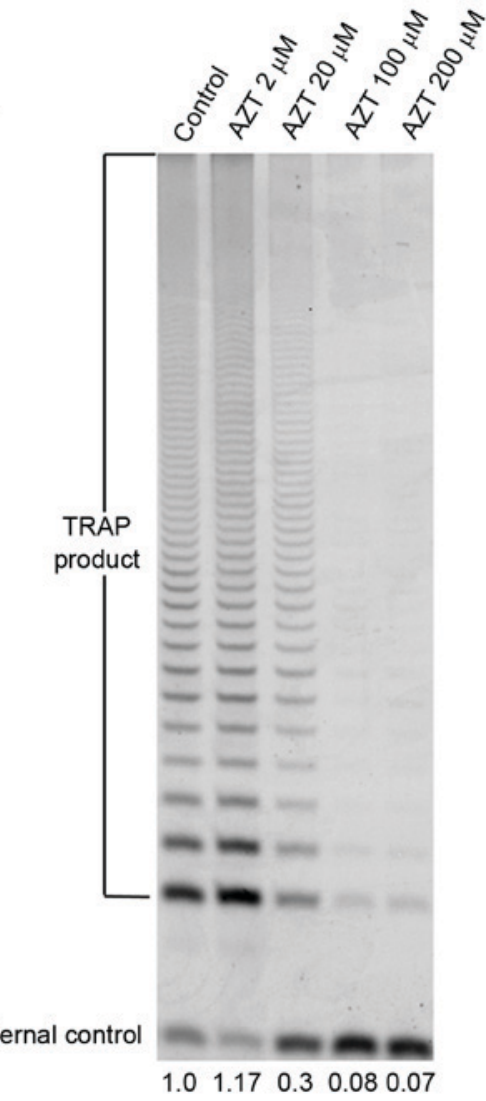

B

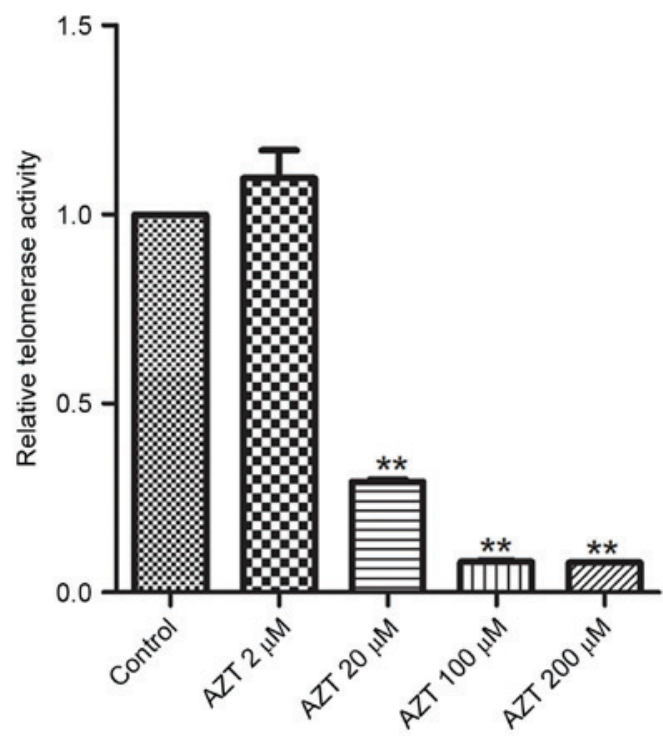

Figure 2. AZT inhibits telomerase activity of TE-11 cells. TE-11 cells were treated with 2, 20, 100 or $200 \mu \mathrm{M}$ AZT for $48 \mathrm{~h}$ and were subjected to a TRAP assay for measurement of telomerase activity. (A) Gel electrophoresis of PCR products. An internal control was included and was evident by a 36 bp PCR product. (B) Telomerase activity was determined by normalizing the TRAP product to the internal control, which was assigned a value of 1 . The values represent the mean \pm standard deviation of three independent experiments. ${ }^{* *} \mathrm{P}<0.01$ vs. Control. AZT, azidothymidine. PCR, polymerase chain reaction; TRAP, telomeric repeat amplification.

Statistical analysis. Data are expressed as the mean \pm standard deviation of three experiments. Statistical differences were analyzed using one-way analysis of variance followed by Tukey's post-hoc test via GraphPad Prism software version 5.0 (GraphPad Software, Inc., La Jolla, CA, USA) or Microsoft Excel 2007 software (Microsoft Corporation, Redmond, WA, USA).

\section{Results}

Inhibition of TE-11 cell proliferation by AZT. TE-11 cell proliferation was inhibited following treatment with 20, 100 and $200 \mu \mathrm{M}$ AZT for $0,24,48,72$ and $96 \mathrm{~h}$, as determined by an MTT assay (Fig. 1). However, treatment with $2 \mu \mathrm{M}$ of AZT did not have an inhibitory effect on TE-11 cells. Therefore, the inhibitory effect of AZT was time- and dose-dependent (Fig. 1; Table I).

Inhibition of telomerase activity in TE-11 cells by AZT. The effect of AZT on telomerase activity in TE-11 cells was determined by a TRAP assay. Treatment with 20,100 and $200 \mu \mathrm{M}$ AZT for $48 \mathrm{~h}$ resulted in a dose-dependent decrease in telomerase activity (Fig. 2A and B) compared with the control. 

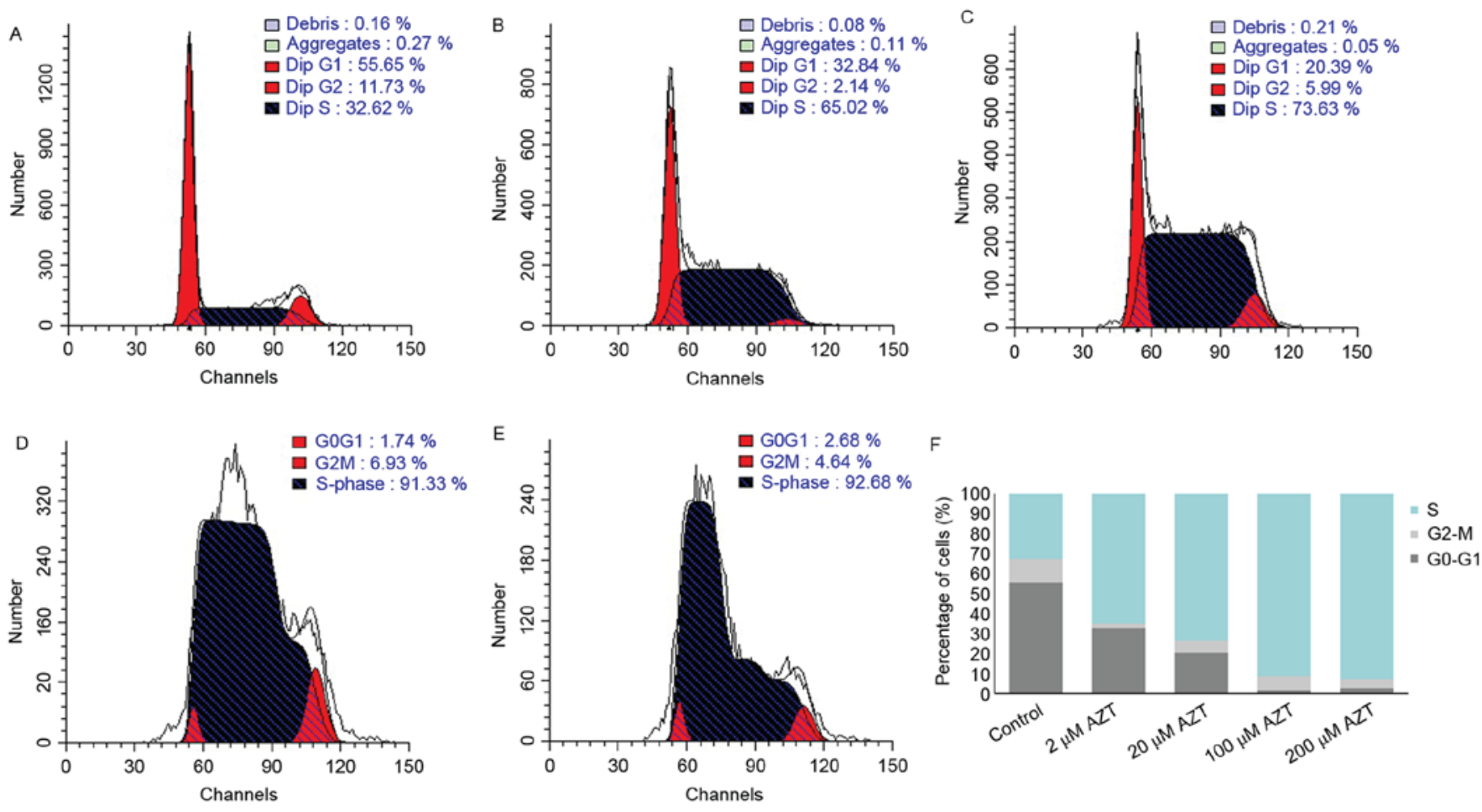

Figure 3. Analysis of cell cycle distribution by flow cytometry. AZT altered the cell cycle of TE-11 cells. Plots demonstrating the cell cycle phases of (A) Control cells and (B) cells treated with $2 \mu \mathrm{M}$ (C) $20 \mu \mathrm{M}$ (D) $100 \mu \mathrm{M}$ (E) $200 \mu \mathrm{M}$ AZT for $48 \mathrm{~h}$. (F) Cell cycle distribution. AZT, azidothymidine.

However, there was no significant difference in activity following treatment with $2 \mu \mathrm{M}$ AZT.

Effect of AZT on cell cycle progression. The effect of AZT on cell cycle distribution was assessed by flow cytometric analysis. Representative cell cycle profiles of TE-11 cells treated with 2, 20, 100 and $200 \mu \mathrm{M}$ AZT for $48 \mathrm{~h}$ are demonstrated in Fig. 3A-E. Treatment with AZT led to a marked dose-dependent decrease in the percentage of G1/G0 phase cells and a marked dose-dependent increase in S-phase cells, compared with the control (Fig. 3F).

Effect of AZT on DNA damage. Degradation of DNA is an irreversible event following apoptotic cascade events (17). To investigate whether treatment with AZT may induce DNA degradation, a comet assay was performed. As demonstrated in Fig. 4A, treatment of TE-11 cells with increasing concentrations of AZT for $48 \mathrm{~h}$ resulted in significant DNA damage compared with control cells; the comet tails of the treated cells demonstrate DNA migration out of the nucleus due to DNA breakage and loss of structure. Consistent with comet assay results, western blot analysis revealed that treatment with increasing concentrations of AZT resulted in enhanced expression levels of $\gamma$-H2AX and pChk2 (Fig. 4B), which are markers of the DNA damage response (DDR) pathway. In conclusion, AZT may induce DNA damage in TE-11 cells.

\section{Discussion}

The majority of cancer cells have been reported to exhibit enhanced telomerase activity, whereas healthy somatic cells generally exhibit a low level of telomerase activity. Previously, telomerase activity has been identified in tumor initiating cells $(3,18)$. Telomerase has been reported to be expressed in $86.2 \%$ esophageal carcinoma tissues; however, healthy esophageal tissue did not express it (19). Therefore, this suggests that there may be a window for telomerase inhibition-based treatment. Repressing telomerase activity may limit cell growth and induce apoptosis. Therefore, telomerase is an attractive target for cancer therapy and various strategies that target telomerase have been applied in clinical practice $(20,21)$.

Telomerase serves a role in abnormal proliferation of tumor cells. A reverse transcriptase inhibitor, AZT, has been utilized in the treatment for AIDS-associated Kaposi sarcoma, Kaposi sarcoma-associated primary effusion lymphoma, Epstein-Barr-associated lymphoma, primary central nervous system lymphoma and adult T cell leukemia (22). AZT has been reported to regress tumors in phase I and II clinical trials, as a single agent or in combination with other drugs for gastrointestinal cancers, pancreatic cancer and various advanced malignancies (23-27). By interacting with hTERT, AZT causes a series of events, including telomere shortening, cell cycle blockade, termination of cellular replication and inhibition of cell growth (10). Chemotherapy is a conventional treatments for esophageal cancer, and is considered to be an essential therapeutic strategy (28). Compared with chemotherapy, AZT may serve as a promising drug as it directly inhibits telomerase activity and causes little injury to healthy cells, and therefore may be less toxic. In the present study, the effects of AZT on TE-11 cells were investigated at various concentrations and time points. 
A

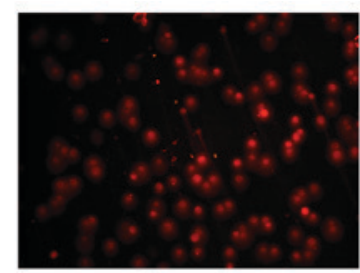

Control

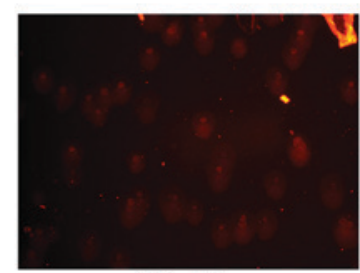

$100 \mu \mathrm{M}$

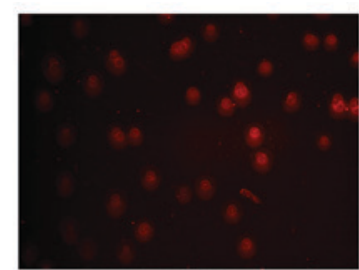

$20 \mu \mathrm{M}$

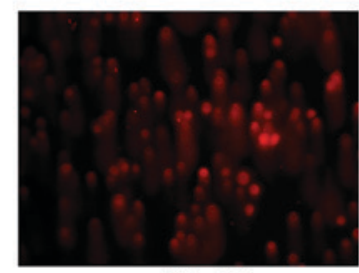

$200 \mu M$
B

$\gamma-\mathrm{H} 2 \mathrm{AX}$

pChk2

$\beta$-actin
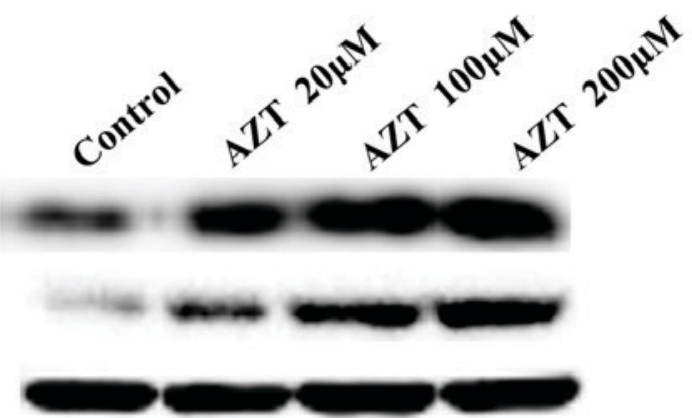

Figure 4. DNA damage by AZT in TE-11 cells was determined by (A) the comet assay and (B) western blotting of $\gamma$-H2AX and pChk2 in Control cells or cells treated with 20,100 and $200 \mu \mathrm{M}$ AZT for 48 h. $\beta$-actin was included as a loading control. AZT, azidothymidine; $\gamma$-H2AX, $\gamma$-H2A histone family member X; pChk2, phosphorylated checkpoint kinase 2 .

Results demonstrated that AZT inhibited telomerase activity and proliferation, delayed cell cycle progression and induced apoptosis of human esophageal cancer TE-11 cells in vitro. The results of the MTT assay revealed that AZT inhibits the growth of cancer cells, which provides an experimental foundation for esophageal tumor therapy. The inhibitory effect was time- and dose-dependent, which suggested that these were important parameters for the treatment of esophageal cancer cells. Treatment of TE-11 cells with AZT resulted in a dose-dependent decrease in telomerase activity and cells in the G1/G0 phase of the cell cycle, and a dose-dependent increase in cells in S-phase. These findings were consistent with previous reports, which demonstrated that AZT arrested NIH3T3 fibroblasts and SGC-7901 gastric cancer cells in S and $\mathrm{G} 2 / \mathrm{M}$ phase $(29,30)$.

Telomerase has been implicated in DNA double strand break (DSB) repair $(31,32)$. To investigate whether AZT affects DNA damage in TE-11 cells, a comet assay was performed following treatment with AZT at various concentrations. DNA damage was enhanced with increasing concentrations of AZT. The expression levels of $\gamma$-H2AX and pChk2, which are markers of the DDR pathway (33), were enhanced following treatment with AZT. Treatment with AZT leads to a reduction in telomerase activity, shortening of telomeres, end-to-end fusions and chromosome instability. In addition, a reduction in telomerase activity interferes with correct rejoining of DSB ends, causes a deficiency in DNA repair and induces apoptosis (31). Telomerase activity is directly associated with protection against cell death, and therefore the inhibition of telomerase in cancer cells leads to apoptosis $(12,14,15)$.

Telomerase as target for cancer treatment has great potential (34). It has been reported that AZT synergistically interacts with other treatment modalities, including chemotherapy agents $(35,36)$. Therefore, AZT may be a novel strategy for the treatment of cancer, including those derived from the esophagus. However, the mechanism by which AZT inhibits cell growth and arrests cell cycle progression in esophageal cancer requires further investigation.

\section{References}

1. Blackburn EH: Telomerases. Annu Rev Biochem 61: 113-129, 1992.

2. Urquidi V, Tarin D and Goodison S: Role of telomerase in cell senescence and oncogenesis. Ann Rev Med 51: 65-79, 2000.

3. Kim NW, Piatyszek MA, Prowse KR, Harley CB, West MD, Ho PL, Coviello GM, Wright WE, Weinrich SL and Shay JW: Specific association of human telomerase activity with immortal cells and cancer. Science 266: 2011-2015, 1994.

4. Pal J, Gold JS, Munshi NC and Shammas MA: Biology of telomeres: Importance in etiology of esophageal cancer and as therapeutic target. Transl Res 162: 364-370, 2013.

5. Li C, Wu MY, Liang YR and Wu XY: Correlation between expression of human telomerase subunits and telomerase activity in esophageal squamous cell carcinoma. World J Gastroenterol 9: 2395-2399, 2003.

6. Mao WM, Zheng WH and Ling ZQ: Epidemiologic risk factors for esophageal cancer development. Asian Pac J Cancer Prev 12: 2461-2466, 2011.

7. Torre LA, Bray F, Siegel RL, Ferlay J, Lortet-Tieulent J and Jemal A: Global cancer statistics, 2012. CA Cancer J Clin 65: 87-108, 2015.

8. Lin Y, Totsuka Y, He Y, Kikuchi S, Qiao Y, Ueda J, Wei W, Inoue $\mathrm{M}$ and Tanaka $\mathrm{H}$ : Epidemiology of esophageal cancer in Japan and China. J Epidemiol 23: 233-242, 2013.

9. Napier KJ, Scheerer M and Misra S: Esophageal cancer: A review of epidemiology, pathogenesis, staging workup and treatment modalities. World J Gastrointest Oncol 6: 112-120, 2014.

10. Gomez DE, Armando RG and Alonso DF: AZT as a telomerase inhibitor. Front Oncol 2: 113, 2012.

11. Ji HJ, Rha SY, Jeung HC, Yang SH, An SW and Chung HC: Cyclic induction of senescence with intermittent AZT treatment accelerates both apoptosis and telomere loss. Breast Cancer Res Treat 93: 227-236, 2005.

12. Li H, Song T, Xu W, Yu Y, Xin X and Hui D: Effect of 3'-Azido-3'-deoxythymidine (AZT) on telomerase activity and proliferation of HO-8910 cell line of ovarian cancer. Int J Biomed Sci 2: 34-40, 2006.

13. Sun YQ, Guo TK, Xi YM, Chen C, Wang J and Wang ZR: Effects of AZT and RNA-protein complex (FA-2-b-beta) extracted from Liang Jin mushroom on apoptosis of gastric cancer cells. World $\mathbf{J}$ Gastroenterol 13: 4185-4191, 2007.

14. Fang JL and Beland FA: Long-term exposure to zidovudine delays cell cycle progression, induces apoptosis, and decreases telomerase activity in human hepatocytes. Toxicol Sci 111: 120-130, 2009.

15. Falchetti A, Franchi A, Bordi C, Mavilia C, Masi L, Cioppi F, Recenti R, Picariello L, Marini F, Del Monte F, et al: Azidothymidine induces apoptosis and inhibits cell growth and telomerase activity of human parathyroid cancer cells in culture. J Bone Miner Res 20: 410-418, 2005. 
16. Pressacco $\mathrm{J}$ and Erlichman $\mathrm{C}$ : Combination studies with 3'-azido-3'-deoxythymidine (AZT) plus ICI D1694. Cytotoxic and biochemical effects. Biochem Pharmacol 46: 1989-1997, 1993.

17. Bröker LE, Kruyt FA and Giaccone G: Cell death independent of caspases: A review. Clin Cancer Res 11: 3155-3162, 2005.

18. Terali K and Yilmazer A: New surprises from an old favourite: The emergence of telomerase as a key player in the regulation of cancer stemness. Biochimie 121: 170-178, 2016.

19. Yu HP, Xu SQ, Lu WH, Li YY, Li F, Wang XL and Su YH: Telomerase activity and expression of telomerase genes in squamous dysplasia and squamous cell carcinoma of the esophagus. J Surg Oncol 86: 99-104, 2004.

20. Shay JW and Wright WE: Telomerase: A target for cancer therapeutics. Cancer Cell 2: 257-265, 2002.

21. Zvereva MI, Zatsepin TS, Azhibek DM, Shubernetskaya OS, Shpanchenko OV and Dontsova OA: Oligonucleotide inhibitors of telomerase: Prospects for anticancer therapy and diagnostics. Biochemistry (Mosc) 80: 251-259, 2015.

22. Datta A, Bellon M, Sinha-Datta U, Bazarbachi A, Lepelletier Y, Canioni D, Waldmann TA, Hermine O and Nicot C: Persistent inhibition of telomerase reprograms adult T-cell leukemia to p53-dependent senescence. Blood 108: 1021-1029, 2006.

23. Posner MR, Darnowski JW, Weitberg AB, Dudley MN, Corvese D, Cummings FJ, Clark J, Murray C, Clendennin N, Bigley J, et al: High-dose intravenous zidovudine with 5-fluorouracil and leucovorin. A phase I trial. Cancer 70: 2929-2934, 1992.

24. Marchbanks K, Dudley MN, Posner MR and Darnowski J: Pharmacokinetics and pharmacodynamics of high-dose zidovudine administered as a continuous infusion in patients with cancer. Pharmacotherapy 15: 451-457, 1995.

25. Clark J, Sikov W, Cummings F, Browne M, Akerley W, Wanebo H, Weitberg A, Kennedy T, Cole B, Bigley J, et al: Phase II study of 5-fluoruracil leucovorin and azidothymidine in patients with metastatic colorectal cancer. J Cancer Res Clin Oncol 122: 554-558, 1996.

26. Miller KD, Loehrer PJ, Gonin R, Weber G, Ansari R, Pletcher W, McClean J, Spiridonidis CH and Mortimer J: A phase II study of weekly oral methotrexate and zidovudine (AZT) in advanced adenocarcinoma of the pancreas and hepatocellular carcinoma. Invest New Drugs 14: 207-212, 1996.
27. Falcone A, Lencioni M, Brunetti I, Pfanner E, Allegrini G, Antonuzzo A, Andreuccetti M, Malvaldi G, Danesi R, Del Tacca M and Conte PF: Maximum tolerable doses of intravenous zidovudine in combination with 5-fluorouracil and leucovorin in metastatic colorectal cancer patients. Clinical evidence of significant antitumor activity and enhancement of zidovudine-induced DNA single strand breaks in peripheral nuclear blood cells. Ann Oncol 8: 539-545, 1997.

28. Lin SH and Chang JY: Esophageal cancer: Diagnosis and management. Chin J Cancer 29: 843-854, 2010.

29. Fang JL, McGarrity LJ and Beland FA: Interference of cell cycle progression by zidovudine and lamivudine in NIH 3T3 cells. Mutagenesis 24: 133-141, 2009.

30. Sun L and Wang X: Effects of allicin on both telomerase activity and apoptosis in gastric cancer SGC-7901 cells. World J Gastroenterol 9: 1930-1934, 2003

31. Zhou FX, Liao ZK, Dai J, Xiong J, Xie CH, Luo ZG, Liu SQ and Zhou YF: Radiosensitization effect of zidovudine on human malignant glioma cells. Biochem Biophys Res Commun 354: 351-356, 2007.

32. Nugent CI, Bosco G, Ross LO, Evans SK, Salinger AP, Moore JK, Haber JE and Lundblad V: Telomere maintenance is dependent on activities required for end repair of double-strand breaks. Curr Biol 8: 657-660, 1998.

33. Oka K, Tanaka T, Enoki T, Yoshimura K, Ohshima M, Kubo M, Murakami T, Gondou T, Minami Y, Takemoto Y, et al: DNA damage signaling is activated during cancer progression in human colorectal carcinoma. Cancer Biol Ther 9: 246-252, 2010.

34. Chen Z and Corey DR: Telomerase inhibitors: A new option for chemotherapy. Adv Cancer Res 87: 31-58, 2003.

35. Chen C, Zhang Y, Wang Y, Huang D, Xi Y and Qi Y: Synergic effect of 3'-azido-3'-deoxythymidine and arsenic trioxide in suppressing hepatoma cells. Anticancer Drugs 22: 435-443, 2011.

36. Mattson DM, Ahmad IM, Dayal D, Parsons AD, Aykin-Burns N, Li L, Orcutt KP, Spitz DR, Dornfeld KJ and Simons AL: Cisplatin combined with zidovudine enhances cytotoxicity and oxidative stress in human head and neck cancer cells via a thiol-dependent mechanism. Free Radic Biol Med 46: 232-237, 2009. 